\title{
Editorial \\ Metallic Materials and Their Applications in Aerospace and Advanced Technologies
}

\author{
Michel Arrigoni (D)
}

check for

updates

Citation: Arrigoni, M. Metallic Materials and Their Applications in Aerospace and Advanced

Technologies. Metals 2022, 12, 226. https://doi.org/10.3390/ met12020226

Received: 4 January 2022

Accepted: 4 January 2022

Published: 26 January 2022

Publisher's Note: MDPI stays neutral with regard to jurisdictional claims in published maps and institutional affiliations.

Copyright: (C) 2022 by the author. Licensee MDPI, Basel, Switzerland. This article is an open access article distributed under the terms and conditions of the Creative Commons Attribution (CC BY) license (https:// creativecommons.org/licenses/by/ $4.0 /)$.
ENSTA Bretagne, IRDL, 29806 Brest, France; michel.arrigoni@ensta-bretagne.fr

\section{Introduction and Scope}

Exploring the mysteries of the universe, transporting people over longer distances in the safest way, providing energy to a growing global population, and facing environmental changes are among the major challenges that will face humanity in the coming decades:

- Satellite observations have become essential in monitoring the ecological health of the Earth, but they require space launches that raise the paradox of greenhouse and toxic gases rejection by the use of solid propellants [1,2]. Space activities also generate space debris that are more and more commonly identified as a scourge in Low Earth Orbital activities [3]. Limitation of the production of microdebris and the design of spacecraft structures able to survive their dynamic interactions [4-6] have become new challenges for the space industry. Space shuttle launches still largely involve carbon-based propellants. Greener launching methods are expected in the near future; liquid hydrogen may create new prospects [7].

- $\quad$ Energy production remains a key issue for our technological world that is also limited by the need to reduce greenhouse gas emissions by nearly $90 \%$ by 2050 compared to 1990. Renewable energy is one of the possible methods than can help to achieve the Cost, Environment, Security, and Job Opportunities quadrilemma [8]. However, energy harvesting is strongly dependent on wind, sun, or water, which cannot provide constant efficiency from day to day or even across seasons, especially in situations with strong local demands when energy storage cannot be sufficient. Renewable energy can then be provided by carbonless energy such as the use of hydrogen $[9,10]$ and nuclear energy [11] with life cycle assessment considerations [12].

- Transportation is also undergoing reorganization. This sector is also strongly intricated in the quadrilemma of Cost, Environment, Reliability, and Job Opportunities. The automotive industry is connected to transportable energy by the expansion of electric cars. The recent development of liquid hydrogen as a carbonless energy is also raising challenges [13], even in aircraft propulsion [14].

- The industry of the future is going to be composed of new materials and innovative production processes that must cope with energetic and recycling constraints and remain cost effective at the same time. This cannot be achieved without the involvement of advanced technologies. Among new materials, micro and nano-structured materials and meta and lattice materials have attracted the interest of the scientific community. Innovative industrial processes such as in the field of metal forming relying on high pulsed power with electromagnetic sources [15] and pulsed laser sources [16] are revolutionizing the manufacturing industry. In recent years, additive methods [17] and processing technologies such as electromagnetic and explosive welding $[18,19]$ and stir welding [20] have also met incremental evolutions, allowing for the extension of forming limits and multimaterial assemblies. In any case, the reliability of resulting products and new materials needs to be characterized in terms of mechanical behavior.

In all of the mentioned challenges, metallic materials and structures stand in the spinal column of space, transportation and energy production systems. The optimization of their 
properties, assemblies and production can ensure progress in the quadrilemma of Cost, Environment, Security and Job Opportunities.

This Special Issue of Metals addresses the most relevant works among the received papers that present an in-depth understanding of the relationships between the structure, properties, or functions of all types of metals involved in aerospace and advanced technologies.

\section{Contribution}

At least two contributions describe new insights into advanced manufacturing that compose new assets for the industry of the future, especially in the field of aerospace.

The paper by Liew et al. [21] addresses the optimization of the Friction Stir Processing (FSP) of recycled aluminum alloy AA6063, commonly used in the automotive and space industries. It was proposed by the Faculty of Engineering and Technology, Jalan Ayer Keroh Lama in Malaysia. FSP is an industrial process [22] derived from Friction Stir Welding [20] that enhances the mechanical behavior of a processed material by hardening. The local strain refines the microstructure of grains, resulting in a superplasticity and a higher corrosion and fatigue strength without creating a heat-affected zone [23]. The FSP tool is a non-consumable pin that comes in contact with a material surface undergoing treatment. Among the analyzed key parameters of FSP, for a given tool geometry, one can note the tool rotational speed, tool transverse speed, depth of penetration into a material, and the tool inclination. Despite the fact that a large variety of tool pin geometries were analyzed, no clear influence could be drawn by Liew et al; they determined that "tapered threaded design offers the best results while [ ... ] triangular and square pin profiles result in the least defects in FSP". Additionally, they carried out an experimental approach in which they studied the relationship between microstructure and microhardness evolution. In their approach, they selected two FSP tool geometries-Straight Cylindrical Threaded (CTH) and Taper Threaded (TTH) - by varying tool rotational speed (1150, 1200, and $1250 \mathrm{rpm})$ and feed rate $(20,25$, and $30 \mathrm{~mm} / \mathrm{min})$. The initial Hardness Vickers of the treated sample was $37.8 \mathrm{HV}$, while it increased up to $62.1 \mathrm{HV}$ for the best configuration. This promising result, obtained with regard to recycled aluminum, emphasized the interest in FSP in high added-value industries, and especially om increasing the fatigue and corrosion strength of lightweight alloys.

The work presented by Birkhofer et al. [24] is a numerical analysis that used the Finite Elements Method (FEM) of the mandrel of a fixture hardening process for aerospace gear box components. The work is a collaboration between Aerospace Transmission Technologies (a Joint Company of Liebherr-Aerospace and Rolls-Royce) and the Leibniz-Institute for Materials Engineering in Bremen. The proposed model involves Multiphysics. It is complex but well detailed and is implemented as a specific user law in the model [25]. In this paper, the mandrel was made of steel alloy S156, and the fact that it was experimentally characterized makes this work very valuable. During the manufacturing of the mandrel, its diameter was actually affected by various processes such as austenitization and mechanical pressing. The authors investigated the influence of the mandrel diameter on the contact force and plasticity in depth. To do so, they developed a coupled thermomechanical-metallurgical FEM model of the mandrel that considered temperature, species diffusion and phase transformation coupled with a nonlinear constitutive law. They found that the applied heat transfer coefficients can cause a recess, thermal gradients, and "nonuniform shrinkage of the part". They also explained how a larger mandrel diameter yields the "lowest contact pressure and lowest force per area" and thus a lower distortion and peak pressure. This work points out the strength of Multiphysics coupling in metal processing. This type of approach lays the foundations of artificial intelligence in manufacturing.

A third paper of interest, by Karlik et al. [26], is the work of a Franco-Czech collaboration supported by the European Regional Development Fund and relates to the microstructure evolution of an age-hardened $\mathrm{CuCr} 1 \mathrm{Zr}$ alloy subjected to direct electrical current heating. This copper alloy is of primary interest as it is closely involved in high electric current applications, ingot molds in metallurgy, and functions as a heat sink of 
the International Thermonuclear Experimental Reactor (ITER) divertor. So, the proposed research fulfils the need to better understand new metallic alloys and their properties for their use in the optimization of the industry of energy production. In this work, the authors noticed that the $\mathrm{CuCr} 1 \mathrm{Zr}$ alloy subjected to a high temperature may lead to weakened mechanical properties and engender electrical short-cut, for instance, as was previously observed in research regarding weld spots [27]. In the presented work, the sample heating was performed in a Gleeble thermal-mechanical simulator at $800{ }^{\circ} \mathrm{C}$, and the temperature was measured using thermocouples. The effects on the microstructure evolution were monitored using microhardness Vickers (HV) measurements and Transmission Electron Microscopy (TEM). The authors gave a comprehensive description of the microstructure evolution with respect to the temperature and hardness gradients. These results are a first steppingstone towards the widespread thermo-mechanical modeling of $\mathrm{CuCr} 1 \mathrm{Zr}$ in advanced technology systems.

In addition to these research works, two relevant reviews were published; both can be connected to the domains of transportation, energy, and aerospace.

The first addresses cryogenic materials used in the storage and transportation of liquid hydrogen, presented by Qiu et al. [28] and funded by the National Natural Science Foundation of China. In this paper, the authors assert that "liquid hydrogen and the hydrogen energy industry have become the key direction of energy development in China" for defense, space, and energy purposes. Due to its low temperature $\left(30^{\circ} \mathrm{K}\right)$, to be stored in a liquid state, hydrogen requires specific materials. However, the lack of standards to guide the design of storage and transportation containers poses a risk. Potential metallic materials for use in cryogenic applications (stainless steel, aluminum alloys and titanium alloys) as well as cryogenic composites, are presented, and their properties are compared with respect to temperature evolution. This paper constitutes an interesting database for cryogenic applications. This overview suggests new insights for future regulations and standards that will strive to solve the quadrilemma evoked in the introduction.

Another relevant review also drew our attention: a review of Intermediate Strain Rate Testing Devices proposed by Bhujangrao et al. [29]. This work is a Franco-Spanish collaboration supported by the European Union's Marie Skłodowska-Curie Actions (MSCA) Innovative Training Networks (ITN). By intermediate strain rate, the authors mean 101 to $103 \mathrm{~s}^{-1}$, which is more representative of accidental situations such as crash tests, bursts, and explosions but also of metal-forming processes [30]. The most common equipments include high-speed servo-hydraulic machines, drop towers, and Hopkinson bars. The flying wheel is also introduced and appears as an original device [31]. The didactic aspect of this document is much appreciated. Again, this review is of importance with regard to transportation safety and metal processing for the industry of the future. Associated measurement methods are described, and some future evolutions are discussed. It is a good introduction paper that studies the dynamic behavior of materials.

\section{Concluding Remarks}

As outlined in the introduction, our technological world has limitations that can be waived by innovation driven by science in key sectors, including the space industry, energy production, and the industry of the future. The evolution that follows must fulfil the quadrilemma that considers Cost, Environment, Security, and Job Opportunities. In this Special Issue, three original research papers and two review address "Metallic Materials and Their Applications in Aerospace and Advanced Technologies", in which new insights and findings are described. Even though the number of submissions remains low, the accepted papers directly concern energy production, storage, and metal processing with regard to the space industry. Many open issues remain to be solved in this context, but as Guest Editor, I hope that this Special Issue provides a substantial impact and also draws the attention of the scientific community and the industry. 
Funding: This research received no external funding.

Institutional Review Board Statement: Not applicable.

Acknowledgments: As a guest editor, I would like to thank the section managing editor Marina Tian for her helpfulness and the editorial board of the Metals journal. Special thanks go to all authors and reviewers; without their appreciated contribution, this Special Issue could have not existed.

Conflicts of Interest: The author declares no conflict of interest.

\section{References}

1. Durrieu, S.; Nelson, R.F. Earth observation from space-The issue of environmental sustainability. Space Policy 2013, 29, 238-250. [CrossRef]

2. Dallas, J.A.; Raval, S.; Gaitan, J.A.; Saydam, S.; Dempster, A.G. The environmental impact of emissions from space launches: A comprehensive review. J. Clean. Prod. 2020, 255, 120209. [CrossRef]

3. Pusey, N. The case for preserving nothing: The need for a global response to the space debris problem. Colo. J. Int'l Envtl. L. Pol'y 2010, 21, 425.

4. Jaulin, V.; Chevalier, J.M.; Arrigoni, M.; Lescoute, E. Characterization of a carbon fiber composite material for space applications under high strains and stresses: Modeling and validation by experiments. J. Appl. Phys. 2020, 128, 195901. [CrossRef]

5. Pelton, J.N. New Solutions for the Space Debris Problem; Springer International Publishing: Cham, Switzerland, 2015.

6. Rossi, A.; Colombo, C.; Tsiganis, K.; Beck, J.; Rodriguez, J.B.; Walker, S.; Kim, Y. ReDSHIFT: A global approach to space debris mitigation. Aerospace 2018, 5, 64. [CrossRef]

7. Trushlyakov, V.; Shatrov, Y. Improving of technical characteristics of launch vehicles with liquid rocket engines using active onboard de-orbiting systems. Acta Astronaut. 2017, 138, 19-27. [CrossRef]

8. Olabi, A.G. Energy quadrilemma and the future of renewable energy. Energy 2016, 108, 1-6. [CrossRef]

9. Felseghi, R.A.; Carcadea, E.; Raboaca, M.S.; Trufin, C.N.; Filote, C. Hydrogen fuel cell technology for the sustainable future of stationary applications. Energies 2019, 12, 4593. [CrossRef]

10. Sherif, S.A.; Goswami, D.Y.; Stefanakos, E.K.; Steinfeld, A. (Eds.) Handbook of Hydrogen Energy; CRC Press: Boca Raton, FL, USA, 2019

11. Hillerbrand, R. The role of nuclear energy in the future energy landscape: Energy scenarios, nuclear energy, and sustainability. In The Ethics of Nuclear Energy: Risk, Justice, and Democracy in the Post-Fukushima Era; Cambridge University Press: Cambridge, UK, 2015; pp. 231-249.

12. Serp, J.; Poinssot, C.; Bourg, S. Assessment of the Anticipated Environmental Footprint of Future Nuclear Energy Systems. Evidence of the Beneficial Effect of Extensive Recycling. Energies 2017, 10, 1445. [CrossRef]

13. Aziz, M. Liquid hydrogen: A review on liquefaction, storage, transportation, and safety. Energies 2021, 14, 5917. [CrossRef]

14. Rompokos, P.; Rolt, A.; Nalianda, D.; Isikveren, A.T.; Senné, C.; Gronstedt, T.; Abedi, H. Synergistic technology combinations for future commercial aircraft using liquid hydrogen. J. Eng. Gas Turbines Power 2021, 143, 071017. [CrossRef]

15. Psyk, V.; Risch, D.; Kinsey, B.L.; Tekkaya, A.E.; Kleiner, M. Electromagnetic forming-A review. J. Mater. Processing Technol. 2011, 211, 787-829. [CrossRef]

16. Ngiejunbwen, L.A.; ShangGuan, J.; Asamoah, E.; Ren, Y.; Ye, Y.; Tong, Y. Experimental investigation of sheet metal forming of Aluminum 2024 using nanosecond pulsed Nd: YAG laser. Opt. Laser Technol. 2021, 133, 106528. [CrossRef]

17. Gibson, I.; Khorasani, A.M. Metallic additive manufacturing: Design, process, and post-processing. Metals 2019, 9, 137. [CrossRef]

18. Wang, H.; Wang, Y. High-velocity impact welding process: A review. Metals 2019, 9, 144. [CrossRef]

19. Tartière, J.; Arrigoni, M.; Nême, A.; Groeneveld, H.; Van Der Veen, S. PVDF Based Pressure Sensor for the Characterisation of the Mechanical Loading during High Explosive Hydro Forming of Metal Plates. Sensors 2021, 21, 4429. [CrossRef] [PubMed]

20. Singh, R.P.; Dubey, S.; Singh, A.; Kumar, S. A review paper on friction stir welding process. Mater. Today Proc. 2021, 38, 6-11. [CrossRef]

21. Liew, K.W.; Chung, Y.Z.; Teo, G.S.; Kok, C.K. Effect of Tool Pin Geometry on the Microhardness and Surface Roughness of Friction Stir Processed Recycled AA 6063. Metals 2021, 11, 1695. [CrossRef]

22. Li, K.; Liu, X.; Zhao, Y. Research status and prospect of friction stir processing technology. Coatings 2019, 9, 129. [CrossRef]

23. Su, J.Q.; Nelson, T.W.; Sterling, C.J. Grain refinement of aluminum alloys by friction stir processing. Philos. Mag. 2006, 86, 1-24. [CrossRef]

24. Birkhofer, H.; Lübben, T.; Taylor, B. Optimizing Mandrel Dimensions for a Fixture Hardening Process of High-Strength Steel Aerospace Parts by Finite Element Simulation. Metals 2020, 10, 303. [CrossRef]

25. Schicchi, D.; Caggiano, A.; Lübben, T.; Hunkel, M.; Hoffmann, F. On the mesoscale fracture initiation criterion of heterogeneous steels during quenching. Mater. Perform. Charact. 2017, 1, 80-104. [CrossRef]

26. Karlík, M.; Haušild, P.; Pilvin, P.; Carron, D. Evolution of the Microstructure of a CuCr1Zr Alloy during Direct Heating by Electric Current. Metals 2021, 11, 1074. [CrossRef]

27. Gauthier, E.; Carron, D.; Rogeon, P.; Pilvin, P.; Pouvreau, C.; Lety, T.; Primaux, F. Numerical modeling of electrode degradation during resistance spot welding using CuCrZr electrodes. J. Mater. Eng. Perform. 2014, 23, 1593-1599. [CrossRef] 
28. Qiu, Y.; Yang, H.; Tong, L.; Wang, L. Research progress of cryogenic materials for storage and transportation of liquid hydrogen. Metals 2021, 11, 1101. [CrossRef]

29. Bhujangrao, T.; Froustey, C.; Iriondo, E.; Veiga, F.; Darnis, P.; Mata, F.G. Review of Intermediate Strain Rate Testing Devices. Metals 2020, 10, 894. [CrossRef]

30. Jeanson, A.C.; Bay, F.; Jacques, N.; Avrillaud, G.; Arrigoni, M.; Mazars, G. A coupled experimental/numerical approach for the characterization of material behaviour at high strain-rate using electromagnetic tube expansion testing. Int. J. Impact Eng. 2016, 98, 75-87. [CrossRef]

31. Froustey, C.; Lambert, M.; Charles, J.L.; Lataillade, J.L. Design of an impact loading machine based on a flywheel device: Application to the fatigue resistance of the high rate pre-straining sensitivity of aluminium alloys. Exp. Mech. 2007, 47, 709-721. [CrossRef] 